\title{
Abstracts from the 4th International Conference on Nursing
}

\author{
Use of Full Outline of Unresponsiveness (FOUR) scale and Alert Verbal Pain Unresponsiveness \\ (AVPU) scale to assess the level of consciousness in head injury patients: A systematic review \\ Annisa Rahmania \\ Student, Master of Nursing Program, Universitas Brawijaya, Malang, Indonesia
}

\section{Introduction}

Head injury as a result of trauma can occur at any age, with damage to both internal and external parts of the head. Assessing the clinical condition of the patient requires predictors such as the Full Outline of UnResponsiveness (FOUR) scale or the Alert Verbal Pain UnResponsiveness (AVPU) scale. The aim of this study was to assess the effectiveness of the FOUR scale and AVPU scale in assessing the level of consciousness in head injury patients.

Methods

This systematic review was conducted by searching and analysing all eligible studies from 2008 to 2017 through the electronic databases ScienceDirect, ProQuest and Google Scholar.

Results

48 articles were found: 10 via ScienceDirect, 16 via ProQuest and 22 via Google Scholar, with only six meeting the criteria. The results show that both FOUR and AVPU have their own advantages.

Conclusion

FOUR and AVPU can be used to assess the level of consciousness in head injury patients but more research needs to be done to find out which of these scales is the more effective.

Keywords

Full Outline of Unresponsiveness (FOUR) Scale; Alert Verbal Pain Unresponsiveness (AVPU) Scale; level of consciousness; head injury patients

\section{Penggunaan Instrumen Full Outline of Unresponsiveness (FOUR) dan Alert Verbal Pain Unresponsiveness (AVPU) dalam Menilai Tingkat Kesadaran pada Pasien Cedera Kepala: Sistematik Review \\ Annisa Rahmania}

Student, Master of Nursing Program, Universitas Brawijaya, Malang, Indonesia

\section{Latar Belakang}

Cedera kepala merupakan dampak yang dihasilkan dari trauma yang bisa terjadi di semua usia yang dapat menyebabkan kerusakan di kepala tidak hanya pada bagian internal namun juga pada bagian eksternal. Untuk melihat kondisi klinis pasien pasca terjadinya cedera diperlukan sebuah prediktor. Prediktor yang digunakan yaitu berupa skala yang digunakan untuk menilai kesadaran pasien, misalnya Full Outline of UnResponsiveness (FOUR), dan juga Alert Verbal Pain Unresponsiveness (VPU) Metode

Systematic review dilakukan dengan mencari dan menganalisis semua studi yang memenuhi syarat dari tahun 2008 - 2017 melalui basis data elektronik: Science Direct, ProQuest, dan Google Scholar.

Hasil

Temuan berupa 48 artikel. 10 artikel didapatkan dari Science Direct, 16 artikel didapatkan dari ProQuest, dan 22 artikel didapatkan dari Google Scholar, tetapi hanya 6 artikel yang sesuai dengan kriteria. Hasil dari diskusi menunjukkan bahwa skala FOUR dan skala AVPU memiliki kelebihan masing-masing.

Kesimpulan

Skala FOUR dan skala AVPU daat digunakan untuk menilai tingkat kesadaran pasien dengan cedera kepala tetapi diperlukan penelitian lebih lanjut untuk mengetahui skala yang lebih efektif antara skala FOUR dan skala AVPU.

Kata kunci

Full Outline of Unresponsiveness (FOUR) Scale; Alert Verbal Pain Unresponsiveness (AVPU) Scale; tingkat kesadaran; pasien cedera kepala 


\section{Is there any positive impact of the implementation of health education to the community on the}

early detection of stroke using 'FAST'?

Husniyatu Rizqiyah Dhomiri

Student, Master of Nursing Program, Universitas Brawijaya, Malang, Indonesia

Introduction

Most lay people do not recognise the initial symptoms of stroke and do not understand the importance of immediately calling the emergency services, causing delays in the pre-hospital phase of care. Early detection of stroke through the FAST method is important. However, the positive impact of health education to the community is still questionable. This study aims to evaluate the positive impact of health education on the early detection of stroke using the FAST method.

Methods

The guidelines of this systematic review used PRISMA (Preferred Reporting Items for Systematic review and Meta-Analysis). A systematic search using the keywords 1) Act FAST Stroke Campaign and 2) Act FAST Stroke was conducted through Proquest, Google Scholar and Science Direct to obtain the relevant literature. Articles published between 2010 and 2017 were selected. Results

All of the studies in this research mention that health education on the early detection of stroke through the FAST method increases public knowledge about the initial symptoms of stroke; one mentions that through the FAST method the community becomes responsive in seeking information and responding to immediately call emergency services, therefore having a positive impact on the patient receiving thrombolytic therapy.

Conclusion

The result of a systematic review shows that health education on the early detection of stroke through the FAST method has a positive impact on increasing knowledge in the community.

Keywords

health education; community; stroke; FAST

\section{Adakah Dampak Positif dari Terlaksananya Pendidikan Kesehatan kepada Masyarakat tentang Deteksi Dini Stroke Melalui Metode FAST?}

Husniyatu Rizqiyah Dhomiri

Student, Master of Nursing Program, Universitas Brawijaya, Malang, Indonesia

Pendahuluan

Sebagian besar masyarakat awam tidak mengenal gejala awal stroke dan tidak memahami pentingnya untuk segera kontak layanan gawat darurat. Hal ini menjadi penyebab keterlambatan di fase prehospital, sehingga deteksi dini stroke melalui metode FAST penting untuk disosialisasikan. Namun dampak positif dari pendidikan kesehatan tentang FAST masih dipertanyakan.

Tujuan dari studi ini adalah untuk mengevaluasi dampak positif dari pemberian pendidikan kesehatan deteksi dini stroke melalui metode FAST kepada masyarakat

Metode

Panduan untuk systematic review ini menggunakan PRISMA (Prefered Reposting Items for Systematic review and Meta-Analysis). Pencarian sistematis dilakukan melaui Proquest, Google Scholar, Science Direct) untuk memperoleh literatur yang relevan. Artikel yang dipilih adalah yang dipublikasikan antara tahun 2010 - 2017. Kata kunci pencarian mencakup (1) Act FAST Stroke Campaign, (2) Act FAST Stroke.

Hasil

Studi secara keseluruhan menyebutkan bahwa pendidikan kesehatan tentang deteksi dini stroke melalui metode FAST meningkatkan pengetahuan masyarakat tentang gejala awal stroke, satu diantaranya menyebutkan bahwa melalui metode FAST masyarakat menjadi tanggap didalam mencari informasi dan tanggap untuk segera kontak layanan gawat darurat sehingga memberikan dampak positif terhadap keberhasilan dalam mendapatkan terapi trombolitik.

Kesimpulan

Hasil dari systematic review menunjukkan bahwa pendidikan kesehatan tentang deteksi dini stroke melalui FAST memiliki dampak positif yang tinggi didalam meningkatkan pengetahuan.

Kata kunci

pendidikan kesehatan; masyarakat; stroke; FAST 


\section{Types of effective trauma scoring in the assessment of trauma patients: A systematic review}

Irine Yunila Prastyawati

Student, Master of Nursing Program, Universitas Brawijaya, Malang, Indonesia

\section{Introduction}

Trauma to an organ can be life-threatening, therefore rapid and precise assessment is necessary using a trauma scoring system. This study aimed to determine the type of scoring that is most effective in determining the severity of trauma in patients.

\section{Methods}

This study used a literature review based on data search analysis from NCBI, ScienceDirect and ResearchGate for papers published between 2008 and 2017. The inclusion criteria were: patients who experienced trauma at more than 15 years of age, used medical record data, and trauma scoring to assess the severity of the patient's trauma.

Results

351 articles were selected, with six articles selected based on inclusion and exclusion criteria. Assessment of the severity of trauma used the Glasgow Coma Scale (GCS), systolic blood pressure, revised trauma score, trauma and injury severity score and trauma scoring modification.

\section{Conclusion}

The most effective method for scoring trauma is the GCS. The recommendation is to use the GCS scoring method in the assessment of trauma patients.

Keywords

trauma; scoring; effective

\section{Jenis Trauma Scoring yang Efektif Digunakan untuk Menilai Keparahan pada Pasien Trauma: Sebuah Systematic Review}

Irine Yunila Prastyawati

Student, Master of Nursing Program, Universitas Brawijaya, Malang, Indonesia

\section{Latar Belakang}

Trauma adalah cedera pada organ dan menyebabkan kondisi yang mengancam bagi seseorang. Penilaian trauma yang cepat dan tepat diperlukan untuk menilai keparahan trauma pasien. Penelitian ini bertujuan untuk menentukan jenis penilaian yang paling efektif dalam menentukan tingkat keparahan pasien trauma.

Metode

Penelitian menggunakan pendekatan systematic review berdasarkan analisis pencarian data dari NCBI, Sciencedirect, dan Researchgate yang dipublikasikan pada tahun 2008-2017. Kriteria inklusi meliputi pasien yang mengalami trauma dengan usia $>15$ tahun, menggunakan data rekam medis, dan menggunakan trauma scoring untuk menilai tingkat keparahan trauma pasien. Hasil

Hasil penelitian menunjukkan terdapat 351 artikel. Ada 6 artikel yang digunakan pada penelitian ini setelah diseleksi berdasarkan kriteria inklusi dan eksklusi. Penilaian tingkat keparahan trauma yang digunakan Glasgow Coma Scale (GCS), Tekanan Darah Sistolik (SBP), Skor Trauma Revisi (RTS), Trauma dan Cedera Tingkat Keparahan (TRISS) dan modifikasi skor trauma lainnya. Kesimpulan

Jenis trauma scoring yang paling efektif adalah GCS. Rekomendasi penggunaan GCS sebagai salah satu penilaian keparahan dalam kasus trauma. Penggunaan GCS dapat dilakukan di ruang gawat darurat karena sistem penilaiannya yang mudah dan memberikan hasil yang representatif.

Kata kunci

trauma; scoring; efektif 


\section{Factors affecting the occurrence of dead on arrival: A systematic review}

Istha Leanni Muskananfola

Student, Master of Nursing Program, Universitas Brawijaya, Malang, Indonesia; Department of Nursing, Citra Husada Mandiri

Kupang Health School, Indonesia

\section{Background}

Emergency conditions require immediate help so that death and disability can be prevented. This systematic review discussed several factors that affect the occurrence of dead on arrival (DOA).

Method

Articles from ScienceDirect and PubMed using keywords 'dead on arrival', 'DOA' and 'emergency' were searched. Other criteria were: published from 2008 to 2018 and in the form of systematic reviews, original research, retrospective or surveillance studies.

Results

The articles from ScienceDirect (65) and PubMed (29) were reviewed, with 31 article duplications exluded. The review process was continued by reading the abstracts of the remaining 34 articles; seven articles were determined to have fulfilled the requirements and analysed through a research article analysis table. The results of the analysis showed several factors affecting the occurrence of DOA, specifically medical disease factors, trauma conditions and the presence or absence of pre-hospital ambulance facilities.

Conclusion

Factors affecting the occurrence of DOA are medical diseases, trauma conditions and the presence or absence of pre-hospital ambulance facilities. The results of this systematic review can also be a reference for further research, specifically in Indonesia. Keywords

dead on arrival (DOA); factors affecting

\section{Faktor-Faktor Penyebab Kejadian Dead on Arrival (DOA): Sebuah Tinjauan Sistematis}

Istha Leanni Muskananfola

Student, Master of Nursing Program, Universitas Brawijaya, Malang, Indonesia; Department of Nursing, Citra Husada Mandiri Kupang Health School, Indonesia

\section{Latar belakang}

Kondisi kegawatdaruratan membutuhkan pertolongan segera sehingga kematian dan kecacatan dapat dicegah. Pertolongan di awal perlu diusahakan untuk mencegah kematian. Melalui tinjauan sistematis ini dibahas beberapa faktor penyebab kejadian dead on arrival (DOA).

Metode

Artikel penelitian ditelusuri di Sciencedirect dan PubMed dengan kata kunci "dead on arrival and DOA and emergency." Kriteria lainnya adalah diterbitkan dari tahun 2008 hingga 2018, dalam bentuk tinjauan sistematis, hasil penelitian dan penelitian retrospektif atau surveilan. Proses pencarian diilustrasikan melalui bagan prisma.

Hasil

Artikel penelitian yang telah ditelusuri dari Sciencedirect (65) dan PubMed (29) ditelaah kembali, ditemukan 31 duplikasi artikel. Proses telaah dilanjutkan dengan membaca abstrak dari 34 artikel yang tersisa dan ditetapkanlah 7 artikel yang memenuhi syarat dan dianalisis melalui tabel analisis. Hasil analisis menunjukkan beberapa faktor yang menyebabkan kejadian dead on arrival (DOA), yaitu faktor penyakit medikal, kondisi trauma serta ada tidaknya pemanfaatan fasilitas ambulans pra rumah sakit. Kesimpulan

Faktor-faktor penyebab kejadian dead on arrival (doa), yaitu penyakit medikal, kondisi trauma serta ada tidaknya pemanfaatan fasilitas ambulans pra rumah sakit. Hasil tinjauan sistematis ini pun dapat menjadi acuan untuk penelitian selanjutnya terkhususnya di Indonesia.

Kata kunci

dead on arrival (DOA); faktor-faktor penyebab 


\section{Emergency medical services in some countries in the world. How about in Indonesia? A systematic review}

Kristianto Dwi Nugroho

Student, Master of Nursing Program, Universitas Brawijaya, Malang, Indonesia

\section{Background}

Emergency medical services (EMS) in Indonesia began nationally in 2016 with the aim of speeding up handling times and reducing mortality. Development by looking at similar services in various countries is needed in order to get EMS that are ideal and in accordance with the conditions in Indonesia. The purpose this study is to look at the EMS system in several developed countries in the world and compare similar systems in Indonesia.

\section{Method}

The literature review uses several articles from ScienceDirect and ProQuest. The grey literature was also used in this study searching Google Scholar with the keywords 'EMS system', 'EMS' and 'pre-hospital care'.

\section{Results}

The published literature from 2000 to 2017 found six articles that were relevant and in accordance with the research questions. In the literature source, there are five things that influence the development of the EMS system in various countries: background formation, organisation, funding, education of ambulance staff, distribution of staff and management of EMS systems. In Indonesia, there is still inequality in many things. One that needs to be considered is the support of government and all levels of society for the lack of EMS systems.

\section{Conclusion}

The EMS system in Indonesia lags behind compared to other developed countries. Support from the government and all levels of society is needed. National training and standardisation of EMS services is also necessary.

Keywords

EMS; EMS system

\section{Layanan Medis Darurat di Beberapa Negara di Dunia. Bagaimana dengan di Indonesia? Tinjauan Sistematis \\ Kristianto Dwi Nugroho \\ Student, Master of Nursing Program, Universitas Brawijaya, Malang, Indonesia}

\section{Latar Belakang}

Layanan Emergency Medical Services (EMS) di Indonesia dimulai secara nasional pada tahun 2016 dengan tujuan mengurangi layanan darurat yang diperbaiki, mempercepat waktu penanganan dan mengurangi angka kematian. Pengembangan dengan melihat layanan serupa di berbagai negara diperlukan untuk mendapatkan layanan darurat yang ideal dan sesuai dengan kondisi di Indonesia. Tujuan dari penulisan artikel ini untuk melihat sistem EMS di beberapa negara maju di dunia dan membandingkan sistem serupa di Indonesia.

\section{Metode}

Tinjauan pustaka menggunakan beberapa artikel menggunakan Science Direct dan Proquest. Literatur abu-abu juga digunakan dalam penelitian ini, Google Scholar dengan kata kunci "sistem EMS", "EMS", "pre-hospital care". Proses seleksi yang digunakan menggunakan diagram Prisma.

\section{Hasil}

Studi literature dari tahun 2000-2017 didapatkan 6 artikel yang relevan dan sesuai dengan pertanyaan penelitian. Dalam sumber literature didapatkan lima hal yang mempengaruhi perkembangan sistem EMS di berbagai negara. Kelima hal tersebut adalah latar belakang pembentukan, organiasi, pendanaan, edukasi staf ambulan, pembagian staf dan manajemen sistem EMS. Untuk di Indonesia masih banyak terjadi ketimpangan dalam berbagai hal. Salah satu hal yang perlu digaris bawahi adalah dukungan pemerintah dan seluruh lapisan masyarakat terhadap sistem EMS yang masih sangat kurang.

Kesimpulan

Sistem EMS di Indonesia masih sangat jauh tertinggal jika di bandingkan dengan negara-negara maju di Dunia. Dukungan dari pemerintah dan seluruh lapisan masyarakat sangat diperlukan. Pelatihan dan standarisasi pelayanan EMS secara nasional juga sangat diperlukan.

Kata Kunci

EMS; sistem EMS 


\section{Analysis implementation of triage process by nurses pre-hospital and in-hospital for the management of chest pain acute myocardial infarction: A systematic review}

Leni Landudjama

Student, Master of Nursing Program, Brawijaya University, Malang, Indonesia

\section{Introduction}

Healthcare providers should be able to identify the early signs and symptoms of heart disease such as acute myocardial infarction (AMI) with typical symptoms of chest pain according to a triage process. The obstacles still encountered are errors in triage of the patient with chest pain that leads to heart disease and delays in the decision-making process to provide early treatment. The aim of this review was to identify implementation of triage process by nurses pre-hospital and in-hospital for the management of chest pain. Methods

Data collection by searching IISTE, ScienceDirect and ProQuest databases. Keywords were used and articles selected based on inclusion criteria about the triage process by nurses pre-hospital or in-hospital for chest pain management of AMI.

Results

Seven articles were selected and analysed, then discussed. The indicators of accuracy in the triage process of patient chest pain AMI are: need fast and precise decision making, level of knowledge, attitude, professional skills and experience, and participated in emergency training and simulation.

Conclusion

Triage process by nurses in the pre-hospital or in-hospital setting to manage chest pain AMI can be done well and accurately based on fast and precise decision-making, a good level of knowledge, attitude, skills and experience, and supported with emergency training to maintain and improve the rapid, precise and accuracy of triage implementation.

Keywords

triage process; chest pain management; AMl

\section{Analisis Proses Pelaksanaan Triage oleh Perawat di Pre-Hospital dan In-Hospital dalam Manajemen Nyeri Dada IMA (Infark Miokard Akut): Sistematik Review}

Leni Landudjama

Student, Master of Nursing Program, Brawijaya University, Malang, Indonesia

\section{Latar belakang}

Pemberi layanan kesehatan harus mampu mengidentifikasi awal tanda dan gejala penyakit jantung seperti IMA dengan gejala khas nyeri dada sesuai dengan proses triage. Adapun kendala yang masih ditemui yaitu terdapat kesalahan dalam melakukan triage pada pasien nyeri dada yang sebenarnya mengarah pada penyakit jantung dan mempengaruhi keterlambatan proses pengambilan keputusan penanganan awalnya. Jadi, sistematik review ini bertujuan untuk mengidentifikasi proses pelaksanaan triage oleh perawat di pre hospital dan in hospital dalam manajemen nyeri dada IMA.

Metode

Pengumpulan data dengan pencarian/penelusuran penelitian dalam data base IISTE, ScienceDirect, dan Proquest. Kata kunci yang dipakai dalam proses penelusuran dan seleksi berdasarkan kriteria inklusi yaitu proses triage oleh perawat di rumah sakit untuk manajemen nyeri dada IMA.

Hasil

Hasil ini melalui seleksi dan memilih artikel jurnal berdasarkan tujuannya, kemudian didapatkan 7 artikel, dikombinasi dan dianalisi serta didiskusikan. Jadi, indikator keakuratan proses triage pada kasus nyeri dada IMA adalah pengambilan keputusan yang cepat dan tepat, tingkat pendidikan, sikap, keterampilan dan pengalaman profesional, juga mengikuti pelatihan dan simulasi kegawatdaruratan.

Kesimpulan

Proses triage oleh perawat di pre hospital dan in hospital untuk manajemen nyeri dada IMA dapat dilakukan dengan baik dan akurat berdasarkan pada pengambilan keputusan yang cepat dan tepat, tingkat pengetahuan, sikap dan keterampilan yang baik dan pengalaman yang profesional serta didukung dengan adanya pelatihan-pelatihan kegawatdaruratan untuk mempertahankan dan meningkatkan proses pelaksanaan triage yang cepat, tepat dan akurat. Rekomendasi penelitian selanjutnya, membutuhkan penentuan pengoptimalan strategi proses triage pasien IMA.

Kata kunci

proses triage; manajemen nyeri dada; IMA 
The relationship between emotional intelligence and academic achievement among health sciences undergraduate students

Norhaini Majid, Norimah Said, Danyal Omar, Mira Syakila Putri Abdul Jalil, Wan Dzul Aneys Aqilah Wan Mohd Zaki

Centre for Nursing Studies, Faculty of Health Sciences, Universiti Teknologi MARA, Selangor, Malaysia

Introduction

Emotional intelligence is a fundamental human trait, which plays an active role in monitoring the behavioral performance of individuals. This study explored the relationship between emotional intelligence and academic achievement among undergraduate students in the Faculty of Health Sciences at the Universiti Teknologi MARA (UiTM).

Methods:

This study used a cross-sectional study design using a questionnaire of Schutte Self-Report Emotional Intelligence Test (SSEIT) that consists of 33 items to assess the level of emotional intelligence. Academic achievement was measured using grade point average (GPA). The sample of the study was all full-time diploma and degree students in the Health Sciences Faculty from Semester 2, 4, 6 and 8.

Results

The results demonstrated that among 312 students surveyed, $83.7 \%(n=261)$ had high emotional intelligence. For the level of academic achievement, most of the respondents (48.1\%) achieved their GPA level between 3.1 and $3.4(n=150)$.

Conclusion

The results of this study indicate a significant positive relationship between emotional intelligence and academic achievement among the undergraduate students.

Keywords

emotional intelligence; academic achievement; health sciences

\section{Hubungan antara Kecerdasan Emosi dan Pencapaian Akademik di Kalangan Mahasiswa Sains Kesehatan \\ Norhaini Majid, Norimah Said, Danyal Omar, Mira Syakila Putri Abdul Jalil, Wan Dzul Aneys Aqilah Wan Mohd Zaki \\ Centre for Nursing Studies, Faculty of Health Sciences, Universiti Teknologi MARA, Selangor, Malaysia}

\section{Latar Belakang}

Kecerdasan emosi dianggap sebagai salah satu aspek asas peribadi manusia, dan ia berperanan aktif dalam memantau prestasi tingkah laku individu. Kajian ini meneroka hubungan antara kecerdasan emosi dan pencapaian akademik di kalangan pelajar siswazah di Fakulti Sains Kesihatan, Universiti Teknologi MARA (UiTM).

Metode

Kajian ini menggunakan reka bentuk kajian rentas keratan menggunakan soal selidik Schutte Self-Report Emotional Intelligence Test (SSEIT) yang mengandungi 33 item untuk menilai tahap kecerdasan emosi. Pencapaian akademik diukur dengan menggunakan Purata Nilai Gred (GPA). Sampel kajian ini adalah semua pelajar sepenuh masa Diploma dan ljazah pada Fakulti Sains Kesihatan di Semester 2, 4, 6 dan 8.

Hasil

Hasilnya menunjukkan bahawa di antara 312 pelajar yang menjalani kajian, 83.7\% $(n=261)$ mempunyai kecerdasan emosi yang tinggi. Untuk tahap pencapaian akademik, kebanyakan responden $(48.1 \%)$ mencapai tahap IPK mereka antara $3.1-3.4(n=150)$. Kesimpulan

Hasil kajian ini juga menunjukkan hubungan positif yang signifikan antara kecerdasan emosi dan pencapaian akademik di kalangan pelajar Fakulti Sains Kesihatan.

Kata kunci

kecerdasan emosi; pencapaian akademik; sains kesihatan 


\section{Knowledge and attitudes towards mental illness among undergraduate students at the Faculty}

Health Sciences in UiTM Puncak Alam

Roswati Nordin', Nadzirah Hamzah¹, Nora Haszalina Hamizan'1, Liyana Balqis Mohd Takrim¹, Norhaini Majid¹, Mohd Bakri Jali² ${ }^{1}$ Centre for Nursing Studies, Faculty of Health Sciences, Universiti Teknologi MARA, Puncak Alam, Selangor, Malaysia ${ }^{2}$ SIRIM Berhad, Shah Alam, Selangor, Malaysia

\section{Introduction}

Mental illness can be defined as an attitude or emotional disorder occuring in an individual. In Malaysia, mental illness is misunderstood; most people relate it to madness and are simply dismissed as 'gila'. Community knowledge and attitude towards a person with mental illness affects health-seeking behavior. Health sciences students - as members of the community - can influence the community because of their knowledge about and attitudes towards mental illness in people. This research was carried out to determine the level of knowledge and attitudes and correlate that knowledge with attitudes among undergraduate Faculty of Health Sciences students in UiTM Puncak Alam.

Methods

This descriptive cross-sectional study was conducted on 285 students through stratified sampling. Data were collected using a modified version of the questionnaire adapted from previous studies consisting of demographic information, knowledge and attitude towards a person with mental illness.

Results

The findings revealed that a majority of the respondents ( $n=267,93.7 \%)$ had a good level of knowledge about mental illness. Furthermore, most of the respondents $(n=247,86.7 \%)$ also had a positive attitude towards mentally ill people.

Conclusion

It could be concluded that undergraduates of the Faculty of Health Sciences have good knowledge of and a positive attitude towards mentally ill people. Even though there was no relationship between knowledge and attitude towards a mentally ill person, more research is needed to identify that issue.

Keywords

mental health; mental illness; knowledge; attitudes

\section{Pengetahuan dan Sikap Berkenaan Sakit Mental di Kalangan Mahasiswa Fakulti Sains Kesihatan di UiTM Puncak Alam}

Roswati Nordin ${ }^{1}$, Nadzirah Hamzah"1, Nora Haszalina Hamizan', Liyana Balqis Mohd Takrim¹, Norhaini Majid ${ }^{1}$, Mohd Bakri Jali² ${ }^{1}$ Centre for Nursing Studies, Faculty of Health Sciences, Universiti Teknologi MARA, Puncak Alam, Selangor, Malaysia ${ }^{2}$ SIRIM Berhad, Shah Alam, Selangor, Malaysia

Latar Belakang

Penyakit mental dapat didefiniskan sebagai sikap atau gangguan emosi yang terjadi pada individu. Di Malaysia, pada umumnya hal ini dikaitkan dengan sakit mental dan di kategorikan sebagai "Gila". Pengetahuan dan sikap masyarakat terhadap individu yang mempunyai penyakit mental akan mempengaruhi prilaku mencari pertolongan kesehatan dan pengobatan pada individu tersebut. Oleh sebab itu, mahasiswa sains kesihatan yang merupakan bagian dari suatu komunitas dapat mempengaruhi pandangan masyarakat umum karena pengetahuan dan sikap mereka terhadap pasien dengan gangguan jiwa. Studi ini dilaksanakan untuk menentukan tingkat pengetahuan, sikap dan hubungan antara pengetahuan dan sikap mahasiswa Fakultis Sains Kesihatan di UiTM Puncak Alam.

Metode

Studi deskriptif ini melibatkan 285 pelajar sebagai responden dengan proses rekruitmen menggunakan teknik stratified sampling. Data dikumpulkan menggunakan kuesioner yang telah dimodifikasi dari penelitian terdahulu yang terdiri dari demografi, pengetahuan, dan sikap terhadap seseorang yang mempunyai gangguan jiwa.

Hasil

Hasil penelitian menunjukkan bahwa tingkat pengetahuan tentang gangguan jiwa yaitu sangat baik. Mayoritasi responden $\mathrm{n}=267$ (93.7\%) memeiliki pengetahuan yang baik mengenai gangguan jiwa dan menyatakan bahwa orang dengan gangguan jiwa dapat melakukan pekerjaan tetap seperti individu lainnya. Responden juga mempunyai sikap positif terhadap orang dengan gangguan jiwa dimana mayoritas responden $n=247(86.7 \%)$ mempunyai sikap positif.

Kesimpulan

Study ini menyimpulkan bahwa mahasiswa di Fakulti Sains Kesihatan mempunyai pengetahuan yang sangat baik dan sikap positif terhadap orang dengan gangguan jiwa. Meskipun tidak terdapat hubungan antara pengetahuan dan sikap terhadap orang dengan gangguan jiwa, penelitian lebih lanjut perlu diperlukan untuk mengetahui lebih jelas isu tersebut.

Kata kunci

kesihatan mental; sakit mental; pengetahuan; sikap 


\section{Chest trauma resulting from cardiopulmonary resuscitation: A systematic review}

Moch Sukron Prasetyo Nur Afandi

Student, Master of Nursing Program, University of Brawijaya, Malang, Indonesia

Introduction

Chest trauma can be caused by cardiopulmonary resuscitation (CPR) administered to patients with cardiac arrest, with the purpose of saving the patient's life.

Methods

This literature review was conducted by searching and analysing all eligible studies from electronic databases that discuss chest trauma caused by CPR. The data was collected through retrospective analysis of patient medical records and autopsy reports.

Results

16 journal articles from 2004 to 2017 were found and screened, but only five met the inclusion criteria: four from ScienceDirect and one from Pubmed. They were analysed in this literature review, with a total sample of 1199 cases. Many factors have been identified that can influence chest trauma. These factors are: age, gender, duration of CPR administration, the rescuer's professional background, CPR in or out-of-hospital, patients with or without intubation and depth of chest compression administration. Of these factors, only the length and technique of CPR along with professional background have significant effects on chest trauma.

Conclusion

Chest trauma can be a complication of CPR. Health practitioners are expected to determine the influence factors triggering chest trauma so that complications from delivering CPR can be avoided.

Keywords

chest trauma; cardio pulmonary resuscitation; chest compression; in-hospital

\section{Trauma dada pada Cardio Pulmonary Resuscitation (CPR): Sistematic Review Moch Sukron Prasetyo Nur Afandi \\ Student, Master of Nursing Program, University of Brawijaya, Malang, Indonesia}

\section{Latar Belakang}

Salah satu penyebab trauma dada adalah tindakan cardio pulmonary resuscitation (CPR) yang diberikan pada pasien dengan henti jantung. Walaupun tindakan CPR tersebut bertujuan untuk menyelamatkan hidup pasien.

Metode

Literature review ini disusun berdasarkan dari hasil pencarian artikel jurnal di beberapa database jurnal terpercaya yang membahas trauma yang diakibatkan oleh tindakan CPR. Data tersebut dikumpulkan melalui analisa retrospective dari data rekam medis pasien dan hasil autopsy.

Hasil

Enam belas jurnal dianalisa sejak tahun 2004-2017, namun hanya lima jurnal yang masuk dalam kriteria inclusi. Empat artikel jurnal didapatkan dari ScienceDirect dan satu artikel jurnal dari Pubmed Journal database. Total sample sebanyak 1.199 kasus. Banyak faktor yang dapat menyebabkan trauma dada. Adapun faktor-faktor tersebut adalah usia, jenis kelamin, lamanya pemberian CPR, latar profesi penolong, CPR in or out of hospital, pasien dengan intubasi atau tanpa intubasi dan kedalaman pemberian kompresi dada. Dari beberapa faktor tersebut, hanya lamanya pemberian CPR, terknik pemberian kompresi dada yang terlalu dalam dan latar belakang profesi penolong yang secara significant berpengaruh terdapat trauma dada.

Kesimpulan

Trauma dada merupakan salah satu komplikasi dari tindakan CPR. Untuk menghindari terjadinya komplikasi dari tindakan CPR, petugas kesehatan diharapkan mengetahui faktor-faktor yang dapat menjadi pencetus trauma dada sehingga komplikasi dari tindakan CPR tersebut dapat dihindari.

Kata kunci

trauma dada; CPR; kompresi dada; di rumah sakit 


\section{Application of cervical collar for cervical spine immobilisation in trauma patients: A systematic}

review

Rizka Hayyu Nafi'ah

Student, Master of Nursing Program, Universitas Brawijaya, Malang, Indonesia

Introduction

906 per 1 million people in the United States suffer neck and spinal injuries every year, indicating the need for appropriate treatment to reduce disability and death rates. Cervical collars are used to stabilise the neck and spine during the process of extracting, transporting and mobilising the patient. The objective of this study was to identify the application of a cervical collar for cervical spine immobilisation in trauma patients.

Methods

The literature search was conducted systematically through ScienceDirect, ResearchGate, Google Scholar and PubMed to retrieve relevant articles published over the period 2009 to 2018. Keywords included: cervical collar, cervical collar, trauma, cervical spine injury, and neck immobilisation.

Results

There were eight identified studies related to the use of a cervical collar in immobilisation of the cervical spine. The results showed that the use of a cervical collar can immobilise the movement of the cervical spine. However, the use of a cervical collar led to side effects including increased intracranial pressure, jugular venous pressure, respiratory effort, pain and discomfort.

Conclusion

The research concluded that the use of a cervical collar is essential, and there is no evidence to indicate that the use of this treatment is unnessary. Further research is important to prove the benefits of cervical collar use in immobilising the cervical spine.

Keywords

cervical collar; Immobilisation; cervical spine; trauma patient

\section{Penggunaan Cervical Collar dalam Imobilisasi Cervical Spine pada Pasien Trauma: Sistematik Review \\ Rizka Hayyu Nafi'ah \\ Student, Master of Nursing Program, Universitas Brawijaya, Malang, Indonesia}

\section{Latar Balakang}

906 per satu juta penduduk di Amerika Serikat mengalami cedera leher dan tulang belakang setiap tahun, sehingga penanganan secara tepat sangat diperlukan untuk mengurangi angka kecacatan dan kematian. Pengunaan servical collar berfungsi untuk menstabilkan leher dan tulang belakang pada proses ekstrikasi, transport, dan mobilisasi. Penelitian ini bertujuan untuk mengkaji penggunaan servical collar dalam immobilisasi leher dan tulang belakang pada pasien trauma.

Metode

Pencarian literatur dilakukan secara sistematis melalui ScienceDirect, Research Gate, PubMed dan Google Scholar untuk periode 2009 hingga 2018. Kata kunci yang digunakan dalam penelitian ini adalah kerah serviks, leher rahim, trauma, cedera tulang belakang leher, dan imobilisasi leher.

Hasil

Ada 8 studi yang diidentifikasi terkait dengan penggunaan kerah serviks dalam imobilisasi tulang belakang leher. Hasilnya menunjukkan bahwa penggunaan cervical collar dapat melumpuhkan pergerakan tulang belakang leher. Namun, penggunaan cervical collar juga memiliki efek samping peningkatan tekanan intrakranial, peningkatan tekanan vena jugularis, peningkatan usaha pernapasan, rasa sakit dan ketidaknyamanan.

Kesimpulan

Penelitian yang ada tidak menyimpulkan bahwa penggunaan cervical collar tidak bermanfaat. Diperlukan lebih banyak penelitian untuk membuktikan manfaat penggunaan cervical collar terhadap imobilisasi tulang belakang leher.

Kata kunci

cervical collar; immobilisation; cervical spine; pasien trauma 
The accuracy of the paediatric assessment triangle instrument as the first step in a triage system to identify paediatric emergency levels: A systematic review

Indri Wahyuningsih

\section{Introduction}

Assessment of paediatric emergency in triage is not feasible, even for experienced medical staff. The challenge of the process is the condition of the child or the inability to respond to questions. The Paediatric Assessment Triangle (PAT) is an instrument recommended to guide initial assessment in paediatric patient triage. PAT is an assessment using physical signs that can be heard and seen by the examiner, such as appearance, respiratory and circulation. The purpose of this systematic review is to determine the accuracy of PAT.

Methods

A systematic review was designed to complete this study. The data source was obtained from PubMed, ScienceDirect and ProQuest and a literature search using PRISMA flowcharts and appraisal study using JBI tools.

Results

There were 43 eligible articles based on title and abstract; 18 articles from ScienceDirect, 20 from PubMed and five from ProQuest. Finally, six articles that met the inclusion and exclusion criteria were found after assessing the full texts. There are several studies that determined the PAT instrument could be used in the first stage of triage to identify paediatric emergencies with various conditions. In pre-hospital, among 302,103 episodes included there were abnormal PAT findings in 24,120 cases (7.9\%).

\section{Conclusion}

PAT has high accuracy for identifying paediatric emergency conditions in the triage process.

Keywords

PAT; instrument; triage; pediatric emergency

\section{Akurasi Instrumen Pediatric Assesment Triangle (PAT) Sebagai Langkah Awal Pada Proses Triase Dalam Mengidentifikasi Tingkat Kegawatan Pediatrik: Systematic Review \\ Indri Wahyuningsih}

\section{Latar Belakang}

Pengkajian kegawatdaruratan pada pediatrik dalam proses triase adalah hal yang seringkali sulit dilakukan, bahkan bagi tenaga medis yang berpengalaman sekalipun. Kondisi anak yang penuh ketakutan atau ketidakmampuan untuk berespons terhadap pertanyaan menjadi penyebab kesulitan pengkajian. Pediatric Assesment Triangle (PAT) atau segitiga pengkajian pediatrik adalah suatu instrumen yang direkomendasikan untuk menjadi pedoman penilaian awal dalam melakukan triage pada pasien pediatrik. PAT merupakan alat pengkajian cepat yang hanya menggunakan tanda-tanda fisik yang bisa dilihat maupun didengarkan pemeriksa. Tiga aspek yang diobservasi dalam PAT adalah warna kulit, pernapasan dan sirkulasi pada kulit. Tujuan dari systematic review ini adalah untuk menilai akurasi instrumen Pediatric Assesment Triangle (PAT).

Metode

Penelitian ini digunakan dengan menggunakan pendekatan sistematic review. Sumber data didapatkan dari PubMed, Science Direct, dan Google Scolar. Pencarian literatur dilakukan dengan menggunakan diagram prisma serta studi apprasial menggunakan JBI.

Hasil

Terdapat 43 artikel yang memenuhi syarat berdasarkan judul dan abstrak; 18 artikel dari Science Direct; 20 artikel dari PubMed dan 5 artikel dari ProQuest. Pada akhirnya, terdapat 6 artikel yang memenuhi kriteria inklusi dan eksklusi. Ada beberapa penelitian yang mengatakan bahwa instrumen PAT dapat digunakan sebagai langkah awal pada triase untuk menentukan keadaan kegawatan pediatrik dengan berbagai kondisi. Pada penggunaan PAT di area rumah sakit, dari 302.103 kasus ditemukan gambaran PAT yang abnormal sejumlah 24.120 kasus $(7,9 \%)$.

Kesimpulan

PAT memiliki akurasi yang tinggi untuk mengidentifikasi kondisi kegawatan pediatrik pada proses triase.

Kata Kunci

PAT; instrumen; triage; kegawatan pediatrik 


\section{Analysing the effect of educational card games towards the level of knowledge, awareness and willingness as bystander CPR among Polinema students}

Hardiyanto ${ }^{1}$, Achdiat Agoes², Tony Suharsono ${ }^{2}$

${ }^{1}$ Student, Master of Nursing Program, Universitas Brawijaya, Malang, Indonesia

${ }^{2}$ Lecturer, Faculty of Medicine, Universitas Brawijaya, Malang, Indonesia

Introduction

Even though CPR can increase a person's chance of survival, few bystanders are willing to assist a cardiac arrest victim due to a lack of knowledge, awareness and willingness to help. The purpose of this study was to understand the influence of an educational card game in increasing knowledge, awareness and willingness to peform CPR among Polinema students.

Methods

This study was quasi-experimental where the sample was divided into three main groups: standard teaching method; educational card game; and both methods. The participants were 85 students from Politeknik Negeri Malang. Participants were selected using simple random sampling. Measurement tools using questionnaires regarding knowledge, awarenees and willingness were applied before and after intervention.

Results

Result of this study revealed that an educational card game significantly increased the knowledge and awareness of participants $(p<0.05)$. The willingness of participants also increased after intervention, even though not statisticly significant. The knowledge increased because of the information provided in visual form on card games. With increased knowldege, the awareness of respondents also increased. However, this increase cannot significantly enhance the willingness as a bystander to perform CPR if needed as most participants did not want to help the homeless and a victim with blood on their face.

Conclusion

An educational card game is recomended for increasing knowledge, awareness and willingness to perform CPR in the community. Keywords

educational cards games; knowledge; awareness; willingness, cardiopulmonary resucitation; bystander CPR

\section{Analisa Pengaruh 'Educational Cards Games' terhadap Tingkat Pengetahuan (Knowledge), Kesa- daran (Awareness) dan Kesediaan (Willingness) sebagai Relawan RJP pada Mahasiswa Polinema Hardiyanto ${ }^{1}$, Achdiat Agoes ${ }^{2}$, Tony Suharsono ${ }^{2}$}

${ }^{1}$ Student, Master of Nursing Program, Universitas Brawijaya, Malang, Indonesia

2Lecturer, Faculty of Medicine, Universitas Brawijaya, Malang, Indonesia

\section{Latar Belakang}

Bantuan bagi korban henti jantung dari masyarakat masih rendah. Hal ini dikarenakan minimnya pengetahuan, kesadaran dan kesediaan yang dimiliki masyarakat. Padahal bantuan RJP yang diberikan dapat meningkatkan angka keselamatan korban henti jantung. Penelitian ini bertujuan untuk mengetahui pengaruh penggunaan educational card game dalam meningkatkan pengetahuan, kesadaran dan kesediaan sebagai relawan RJP pada mahasiswa Polinema.

Metode

Desain penelitian ini menggunakan quasy experimental dimana responden akan dibagi kedalam 3 kelompok utama yaitu yang menggunakan modul/SAP, educational card game dan kelompok dengan perlakuan gabungan keduanya. Penelitian ini menggunakan responden sebanyak 85 mahasiswa tingkat 1 Politeknik Negeri Malang. Sampel dibagi menggunakan simple random sampling dan diberikan kuesioner tentang pengetahuan, kesadaran dan kesediaan sebagai alat ukur sebelum dan sesudah perlakuan.

Hasil

Hasil penelitian menujukkan penggunaan educational card game meningkatkan tingkat pengetahuan dan kesadaran sebelum dengan setelah perlakuan secara signifikan $(p<0,05)$. Rata-rata tingkat kesediaan responden melakukan RJP juga meningkat setelah diberikan perlakuan walaupun tidak terbukti signifikan. Pengetahuan meningkat karena adanya informasi yang diberikan secara visual didalam kartu. Dengan pengetahuan yang meningkat, kesadaran responden juga ikut meningkat. Namun peningkatan tersebut belum cukup untuk meningkatkan kesediaan responden memberikan bantuan RJP. Banyak dari mereka yang tidak mau memberikan pertolongan pada korban tidak dikenal dan korban dengan darah pada wajah.

Kesimpulan

Educational card game disarankan untuk dapat memperluas pengetahuan, kesadaran dan kesediaanmasyarakat melakukan RJP. Kata kunci

educational cards game; pengetahuan; kesadaran; kesediaan; resusitasi jantung paru; relawan RJP 


\section{Comparison between qSOFA and SIRS criteria in predicting mortality of patients with sepsis}

Efris Kartika Sari

School of Nursing, Universitas Brawijaya, Malang, Indonesia

Introduction

Sepsis is a common cause of mortality in critically ill patients. The Third International Consensus Definitions for Sepsis and Septic Shock (Sepsis-3) Task Force recommend the quick Sequential Organ Failure Assessment (qSOFA) instead of the systemic inflammatory response syndrome (SIRS) criteria to identify patients at high risk of death. The purpose of this paper was to analyse a comparison of the accuracy between qSOFA and SIRS as screening tools for predicting mortality among critically ill patients with sepsis.

Methods

The paper was a literature review: 20 articles relating to qSOFA and SIRS were retrieved and included in the study. The criteria of qSOFA (systolic arterial blood pressure, respiratory rate and altered mental status) and SIRS (tachypnea, tachycardia, leukopenia or leukocytosis and fever or hypothermia) were used as screening tools to identify patients at high risk of having poor outcome and infections.

Results

A qSOFA score of $\geq 2$ and SIRS score of $\geq 2$ were associated with a higher risk of mortality. Previous studies revealed that sepsis was not an exclusive pro-inflammatory condition; rather, it may involve early anti-inflammatory responses. Sepsis-3 was based on organ dysfunctions and used a sequential organ failure score as an index.

Conclusion

Although both qSOFA and SIRS can be used as predictors of mortality, qSOFA was a better predictor of mortality compared to SIRS.

Keywords

qSOFA; SIRS; mortality

\section{Perbandingan antara Kriteria qSOFA dan SIRS dalam Memprediksi Kematian pada Pasien Sepsis Efris Kartika Sari \\ School of Nursing, Universitas Brawijaya, Malang, Indonesia}

\section{Latar Belakang}

Sepsis merupakan penyebab kematian utama pada pasien dengan kondisi kritis. The Third International Consensus Definitions for Sepsis and Septic Shock (Sepsis-3) Task Force telah merekomendasikan untuk menggunakan kriteria quick Sequential Organ Failure Assessment (qSOFA) daripada Systemic inflammatory response syndrome (SIRS) dalam mengklasifikasikan pasien yang memiliki resiko tinggi kematian. Tujuan studi ini adalah untuk menganalisis perbandingan ketepatan antara qSOFA and SIRS sebagai alat instrumen untuk memprediksi kematian pada pasien Sepsis dengan kondisi kritis.

Metode

Studi ini merupakan suatu studi tinjauan literature. akalah ini adalah tinjauan literatur. Dua puluh artikel yang berfokus pada qSOFA dan SIRS diambil dan dimasukkan dalam studi ini. Kriteria qSOFA (tekanan darah arteri sistolik, laju pernapasan, dan perubahan status kesadaran) dan SIRS (takipnea, takikardia, leukopenia atau leukositosis dan demam atau hipotermia) digunakan sebagai alat skrining untuk mengidentifikasi pasien berisiko tinggi yang memiliki outcome yang buruk dan infeksi. Hasil

Skor qSOFA $\geq 2$ dan skor SIRS $\geq 2$ memiliki hubungan dengan risiko kematian yang lebih tinggi. Penelitian sebelumnya mengungkapkan bahwa sepsis bukanlah kondisi proinflamasi eksklusif; melainkan mungkin melibatkan respons anti inflamasi dini. Sepsis-3 didasarkan pada disfungsi organ dan menggunakan skor kegagalan organ berurutan sebagai indeks.

Kesimpulan

Meskipun qSOFA dan SIRS dapat digunakan sebagai prediktor kematian, qSOFA adalah prediktor kematian yang lebih baik dibandingkan dengan SIRS.

Kata kunci

qSOFA; SIRS; kematian 
Work readiness to be an ambulance nurse among nursing graduates in Indonesia

Suryanto ${ }^{1}$, Virginia Plummer ${ }^{2,3}$, Malcolm Boyle ${ }^{4}$

${ }^{1}$ School of Nursing, Universitas Brawijaya, Malang, Indonesia

${ }^{2}$ School of Nursing and Midwifery, Monash University, Australia

${ }^{3}$ Peninsula Health, Victoria, Australia

${ }^{4}$ School of Medicine, Griffith University, Australia

Introduction: The knowledge and skills of pre-hospital care among nurses in Indonesia are essential because nurses are required for staffing ambulance services. However, their knowledge and/or skills related to pre-hospital care might not be sufficient because of a lack of pre-hospital content in the nursing curriculum. This study investigated the work readiness of nursing graduates in Indonesia to work as an ambulance nurse.

Methods: This was a cross-sectional study consisting of a paper-based survey investigating eight domains of work readiness. Using a convenience sampling method, there were 394 new nursing graduates area involved in the study.

Results: Participants' score in the 'ethics and legal responsibilities' domain was the highest (82.1\%) and 'practical skills' domain was the lowest $(65.5 \%)$ domain. Participants aged 29 years or more had the highest scores in all eight domains of the questionnaire. The 'theoretical knowledge' and 'lifelong learning' scores were significantly different based on the time since graduation. Participants' 'clinical skills' and 'practical skills' domains were significantly different based on gender.

Conclusion: This study revealed that nursing graduates in Indonesia need pre-hospital skill content in their education. An amendment of nursing curriculum is required to increase the nurses' competencies in pre-hospital care.

Keywords

ambulance nurse; competency; nurse graduates; pre-hospital; work readiness; Indonesia

\section{Kesiapan Kerja untuk Menjadi Perawat Ambulans bagi Lulusan Perawat di Indonesia}

Suryanto1, Virginia Plummer ${ }^{2,3}$, Malcolm Boyle ${ }^{4}$

${ }^{1}$ School of Nursing, Universitas Brawijaya, Malang, Indonesia

${ }^{2}$ School of Nursing and Midwifery, Monash University, Australia

${ }^{3}$ Peninsula Health, Victoria, Australia

${ }^{4}$ School of Medicine, Griffith University, Australia

\section{Latar Belakang}

Pengetahuan dan keterampilan pelayanan pra rumah sakit bagi perawat di Indonesia sangat penting karena perawat merupakan tenaga kerja utama dalam system layanan ambulan di Indonesia. Namun, pengetahuan dan/atau keterampilan perawat terkait dengan pelayanan pra rumah sakit mungkin tidak cukup karena kurangnya konten pra rumah sakit dalam kurikulum pendidikan keperawatan. Penelitian ini bertujuan untuk mengidentifikasi kesiapan kerja lulusan keperawatan di Indonesia untuk bekerja sebagai perawat ambulans.

Metode

Desain penelitian ini adalah penelitian cross-sectional yang menggunakan survei untuk mengidentifikasi delapan domain kesiapan kerja. Terdapat 394 lulusan perawat baru yang terlibat dalam penelitian ini.

Hasil

Skor peserta dalam domain "etika dan tanggung jawab hukum" adalah yang tertinggi $(82,1 \%)$ dan domain "keterampilan praktis" adalah domain terendah (65,5\%). Peserta yang berusia 29 tahun atau lebih memiliki skor tertinggi di semua delapan domain kuesioner. Nilai "pengetahuan teoritis" dan "pembelajaran seumur hidup" secara signifikan berbeda berdasarkan waktu sejak lulus. Domain "keterampilan klinis" dan "keterampilan praktis" peserta berbeda secara signifikan berdasarkan jenis kelamin.

Kesimpulan

Studi ini mengungkapkan bahwa lulusan keperawatan di Indonesia membutuhkan konten keterampilan pra rumah sakit dalam pendidikan mereka. Amandemen kurikulum keperawatan diperlukan untuk meningkatkan kompetensi perawat dalam pelayanan pra-rumah sakit.

Kata Kunci

perawat ambulans; kompetensi; Iulusan perawat; pra rumah sakit; kesiapan kerja; Indonesia 


\section{Barriers and solutions to implementing an EMS system in Indonesia from decision makers' perspective: A qualitative study}

Suryanto ${ }^{1}$, Virginia Plummer ${ }^{2,3}$, Malcolm Boyle ${ }^{4}$

${ }^{1}$ School of Nursing, Universitas Brawijaya, Malang, Indonesia

${ }^{2}$ School of Nursing and Midwifery, Monash University, Australia

${ }^{3}$ Peninsula Health, Victoria, Australia

${ }^{4}$ School of Medicine, Griffith University, Australia

Introduction

Pre-hospital care in Indonesia is still underdeveloped. The breakthrough with the launch of the 119 Emergency Medical Services

(EMS) occurred some 10 years after the previous 118 EMS system. During those 10 years, the pre-hospital care in Indonesia had been unorganised. This study has investigated the barriers and solutions for implementation an EMS system in Indonesia.

Methods

This was qualitative study utilising semi-structured interview involving seven participants from six cities in Indonesia. Thematic analysis was used to analyse the data.

Results

Six themes relating to barriers to implementing an EMS system in Indonesia were identified. It includes lack of government support, issues with human resources, problems at hospital level, barriers with community awareness, insufficient ambulance vehicles and road traffic. Five themes emerged from the data for providing solutions to the implementation of an EMS system in Indonesia. It comprises implementation of the EMS system, creativity at the local health facilty level, enhancing pre-hospital providers' capacity, government support and community empowering.

Conclusion

This study suggested that the initial implementation of the EMS system is a necessity. There is an expectation that the 119 EMS system can be implemented in all areas of Indonesia so that the prehospital care can be provided to all people within Indonesia. Keywords

EMS system; Indonesia; pre-hospital care; problems; solutions

\section{Hambatan dan Solusi untuk Menerapkan Sistem EMS di Indonesia dari Perspektif Pengambil Kebi- jakan: Studi Kualitatif}

Suryanto ${ }^{1}$, Virginia Plummer ${ }^{2,3}$, Malcolm Boyle ${ }^{4}$

${ }^{1} S c h o o l$ of Nursing, Universitas Brawijaya, Malang, Indonesia

${ }^{2}$ School of Nursing and Midwifery, Monash University, Australia

${ }^{3}$ Peninsula Health, Victoria, Australia

${ }^{4}$ School of Medicine, Griffith University, Australia

\section{Latar Belakang}

Layanan pra-rumah sakit di Indonesia masih jauh dari sempurna. Terobosan dengan peluncuran 119 Emergency Medical Services (EMS) terjadi sekitar sepuluh tahun setelah berhentinya sistem 118 EMS sebelumnya. Selama sepuluh tahun itu, layanan prarumah sakit di Indonesia tidak terorganisir. Studi ini menginvestigasi hambatan dan solusi dalam mengimplementasikan sistem EMS di Indonesia.

Metode

Penelitian adalah studi kualitatif dengan menggunakan wawancara semi terstruktur yang melibatkan tujuh responden dari enam kota di Indonesia. Analisis tematik digunakan untuk menganalisis data.

Hasil

Enam tema yang berkaitan dengan hambatan untuk menerapkan sistem EMS di Indonesia telah teridentifikasi. Hal termasuk meliputi kurangnya dukungan pemerintah, masalah dengan sumber daya manusia, masalah di tingkat rumah sakit, hambatan terkait kesadaran masyarakat, kendaraan ambulans yang tidak memadai dan lalu lintas jalan. Lima tema muncul dari data untuk memberikan solusi dalam mengimplementasikan sistem EMS di Indonesia. Hal tersebut terdiri dari implementasi sistem EMS, kreativitas di tingkat fasilitas kesehatan setempat, peningkatan kapasitas penyedia layanan pra rumah sakit, dukungan pemerintah, dan pemberdayaan masyarakat.

Kesimpulan

Hasil studi mendapatkan bahwa segera mengimplementasikan sistem EMS adalah suatu keharusan. Diharapkan bahwa sistem 119 EMS dapat diimplementasikan di semua wilayah Indonesia sehingga layanan pra rumah sakit dapat diberikan kepada semua orang di Indonesia.

Kata Kunci

sistem EMS; Indonesia; layanan pra rumah sakit; masalah; solusi 